\title{
Minister in charge of suicide prevention knows the crisis intimately
}

W hen Paul Okalik's addiction to alcohol led him to believe he had no other option, he started thinking about the best way to take his own life. "I was contemplating it: what method to use, which would be the cleanest, which would make sure that I was dead and not permanently damaged," he remembers. "What can you do, when you are addicted? You lose control of your life."

That was in 1991, when he was only 27. He eventually became Nunavut's first premier and is now the territory's minister of health; now he's taking the lead on suicide prevention following the Oct. 22 recommendations of an inquest. But in 1991, he lived far from home in Ottawa, where he was a negotiator on the Inuit Lands Claims Agreement. At the time, the dream of a new territory seemed unattainable. So did a hopeful future.

When Okalik was only 13 , his 19-year-old brother, Norman, killed himself. Norman had stolen money to support his drug habit. Although he wasn't caught, his guilty conscience prompted him to confess. He spent six months in jail and was ordered to repay the money. With no way to make restitution and terrified of going back to jail, Norman killed himself.

Paul Okalik was traumatized and angry. "It took me a very long time to forgive those in the law field, because it was a very tragic circumstance which could have been avoided."

By 1991, Paul Okalik had also had brushes with the law and couldn't find a way out of his despair. Suicide seemed like an acceptable solution to the pain.

It wasn't acceptable to Okalik's older sister Ida, though. "We talked to each other every day while I was trying to survive," says Paul Okalik, his voice breaking. "She supported me and explained how tragic it was with my brother passing and how hard it was on my family, and that she did not want to go through that again."

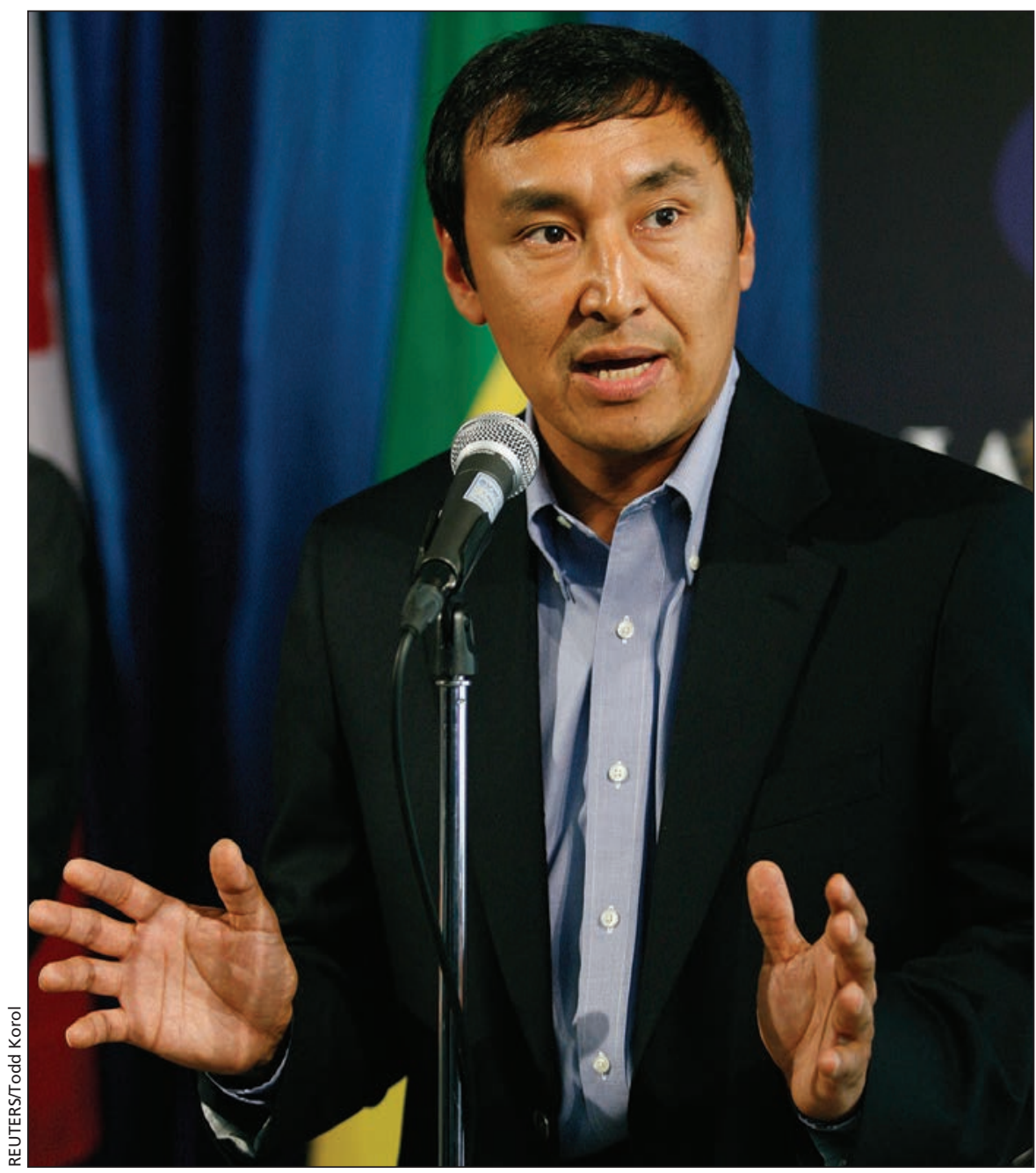

Paul Okalik, Nunavut's former premier, is taking the lead on the territory's new suicide prevention efforts.

"She explained that she loved me, regardless of the circumstances, that I was her baby brother, that she could not lose another."

With Ida's support, Okalik checked himself into a drug and alcohol treatment program. Then he enrolled in university. He also learned that he and his partner were going to have a child. "I became a father that year, and that's when I turned the corner."

Six years later, Okalik graduated from law school. He returned to Nunavut and continued to fight to establish the territory. In 1999, when Nunavut was born, Okalik's fellow members of the legislative assembly elected him the territory's first premier. He was also the first Inuk member called to the Nunavut bar association.

Today, Okalik has returned to office as Nunavut's health minister, where he is presiding over plans to address a public health crisis that has seen nearly 500 Inuit take their own lives since the territory's formation. On Oct. 22, Nunavut's premier, Peter Taptuna, publicly acknowledged that crisis and gave Okalik the 
chair of a new cabinet committee on quality of life that will implement the territory's suicide prevention strategy and action plan, as well as the recommendations of a coroner's inquest into a record 45 deaths by suicide in 2013 alone.

It's a role Okalik says he is honoured to assume. It's also one he could not have imagined during those dark days when he pondered the best way to take his own life.

Coroner Padma Suramala, who called the inquest, believes Okalik will "bring positive changes and implement those recommendations to the best of his ability."

Okalik may be the territory's best chance of having a senior official show leadership on suicide prevention, agrees Jack Hicks, an expert witness at the inquest who has been highly critical of how the territorial government has implemented the suicide prevention strategy to date.

"When he was first elected premier back in 1999, Okalik ensured that the Nunavut government was decentralized. Fifteen years later, the territory needs his determination once again to get a far larger job done," says Hicks, coauthor of Made in Nunavut: An Experiment in Decentralized Government.

Okalik is committed to bringing the government's resources to bear on tackling the suicide crisis, he says. He's also prepared to share his story to help other young people understand that no matter how bleak life seems in the moment, it can get better. - Laura Eggertson, Ottawa, Ont.

CMAJ 2015. DOI:10.1503/cmaj.109-5187 